\title{
Maximization of Productivity in Sodic Soil through Bio-Intensive Complementary Cropping System with Organic Amendments
}

\author{
P. M. Shanmugam ${ }^{*}$ and S. Somasundaram ${ }^{2}$ \\ ${ }^{1}$ Institute of Agriculture, Kumulur - 621712, Tiruchirappalli District, India \\ ${ }^{2}$ Anbil Dharmalingam Agricultural College and Research Institute, Navalur, \\ Kuttapattu - 620027. Tiruchirappalli District, India \\ *Corresponding author
}

\begin{tabular}{|l|}
\hline \multicolumn{1}{|l}{} \\
\hline Key w o r d s \\
Bio intensive, \\
$\begin{array}{l}\text { Complementary } \\
\text { cropping, Poultry } \\
\text { manure, Sodic soil, } \\
\text { FYM }\end{array}$ \\
\hline Article Info \\
\hline $\begin{array}{l}\text { Accepted: } \\
\text { 20 June 2020 } \\
\text { Available Online: } \\
\text { 10 July 2020 }\end{array}$ \\
\hline \hline
\end{tabular}

\section{A B S T R A C T}

Field experiment was conducted at Anbil Dharmalingam Agricultural College and Research Institute, Tiruchirappalli to enhance productivity of sodic soil thorough bio intensive complementary cropping systems with organic amendments. The soil of the experiential field was alkali with pH: 8.8, EC: $0.96 \mathrm{ds} / \mathrm{m}$ and ESP: 17.1. The experiment was laid out in split plot design and replicated thrice. Main plot comprises three complementary cropping system ie. $\mathrm{M}_{1}$ : Maize + Cowpea + Daincha, $\mathrm{M}_{2}$ : Sunflower + Greengram + Daincha and $\mathrm{M}_{3}$ : Bhendi + Onion + Daincha and sub plot comprises five treatment combinations like $\mathrm{S}_{1}: 100 \%$ recommended NPK through fertilizers, $\mathrm{S}_{2}: 50 \%$ recommended NPK through fertilizers $+50 \% \mathrm{~N}$ through $\mathrm{FYM}, \mathrm{S}_{3}: 75 \%$ recommended NPK through fertilizers $+25 \% \mathrm{~N}$ through FYM, $\mathrm{S}_{4}: 50 \%$ recommended NPK through fertilizers $+50 \% \mathrm{~N}$ through poultry manure and $\mathrm{S}_{5}: 75 \%$ recommended NPK through fertilizers $+25 \% \mathrm{~N}$ through poultry manure. Based on the results, it is concluded that complementary cropping of maize + cowpea + daincha with application of $75 \%$ recommended NPK through fertilizers $+25 \% \mathrm{~N}$ through poultry manure may be recommended for sodic soils for soil health improvement and obtained maximum economical benefits.

\section{Introduction}

In India sodic soils have occupied 37.71lakh ha and these soils are essentially located in the Indo-Gangetic plain, arid and semiarid region in Western and Central India and the peninsular region in the Southern India. In the peninsular region, sodic soils have occupied extensive areas in Tamil Nadu, Andhra Pradesh, Telangana and Karnataka state. In Tamil Nadu sodic soils have occupied 3.55 lakh ha and these are essentially found in the central Tamil Nadu covering Ramanathapuram, Cuddalore, Kanchipuram, Tirunelveli, Thanjavur, Pudukottai, Madurai and Tiruchirappalli districts. The combined application of different organic amendments improves their effectiveness for increasing soil properties. Several studies suggested that the application of organics in saline sodic and sodic soil can ameliorate the physical and chemical soil properties such as bulk density, 
hydraulic conductivity, water infiltration, $\mathrm{pH}$, electrical conductivity, exchangeable sodium percent and sodium adsorption. Recently, various organic amendments such as mulch, FYM and compost, have been effectively used to improve salt affected soils. Moreover, organic materials improve the soil physicochemical properties that accelerate exchange of cations on soil solids and leaching of salts from the root zone (Clark et al., 2007). Use and management of crop residues, FYM and green manures are becoming an increasingly important aspect of environmentally sound sustainable agriculture. Long term addition of organic materials to soil results in increased organic matter, crop productivity and soil biological activity. Adoption of suitable cropping system is essential for ensuring the most rational use of land and increasing productivity per unit area per unit time. It is possible to enhance the production potential and remuneration with adoption of alternate productive and profitable cropping. Diversification of the existing cropping through introduction of alternate bio intensive complementary copping may pave way for increased economic benefits over traditional systems along with soil health improvement. Hence, using organic sources like FYM and composted poultry manure deserves priority for sustained production and better resource utilization in salt affected soils. This method was self-sufficient and self-dependent as it is relying more on organic inputs. With this background this project is to be taken up to find out the effect of different organic amendments on production and productivity of different crops under salt affected soils.

\section{Materials and Methods}

Field experiment was conducted at Anbil Dharmalingam Agricultural College and Research Institute, Tiruchirappalli during rabi season of 2016 -2017 to enhance productivity of sodic soil thorough bio intensive complementary cropping systems with organic amendments. The farm is situated in the Cauvery Delta Agro-climatic Zone of Tamil Nadu at $10^{\circ} 45^{\prime} \mathrm{N}$ latitude and $78^{\circ} 36^{\prime} \mathrm{E}$ longitude with an altitude of $85 \mathrm{~m}$ above MSL. The mean maximum and minimum temperatures were $32.7^{\circ} \mathrm{C}$ and $22.3^{\circ} \mathrm{C}$ respectively. The mean relative humidity was 85 per cent in the FN and 58.2 percent in the an and the mean sunshine hours were 5.8. Soil of the experimental field was sandy clay loam and taxonomically the soil belongs to the family Vertic Ustropept having $\mathrm{pH}$ : 8.8, EC: $0.96 \mathrm{ds} / \mathrm{m}$ and ESP: 17.1. The experiment was laid out in split plot design and replicated thrice. Main plot comprises three complementary cropping system ie. $\mathrm{M}_{1}$ : Maize + Cowpea + Daincha, $\mathbf{M}_{2}$ : Sunflower + Greengram + Daincha and $\mathrm{M}_{3}$ : Bhendi + Onion + Daincha and sub plot comprises five treatment combinations like $\mathrm{S}_{1}: \quad 100 \%$ recommended NPK through fertilizers, $\mathrm{S}_{2}$ : $50 \%$ recommended NPK through fertilizers + $50 \% \mathrm{~N}$ through FYM, $\mathrm{S}_{3}: 75 \%$ recommended NPK through fertilizers $+25 \% \mathrm{~N}$ through FYM, $\mathrm{S}_{4}: 50 \%$ recommended NPK through fertilizers $+50 \% \mathrm{~N}$ through poultry manure and $\mathrm{S}_{5}: 75 \%$ recommended NPK through fertilizers $+25 \% \mathrm{~N}$ through poultry manure.

The land configuration for the study was FIRB (Furrow irrigated raised bed). For yield and economic analysis, various crops yield were converted into maize equivalent yield based on the value of the concerned crop produces. The plot size was $5 \mathrm{~m} \times 4 \mathrm{~m}$. In the main plot daincha was sown in the furrow and incorporated 40 days after sowing. Economic analysis was done by computing the cost of cultivation, gross return and net return for each treatment considering the prevailing market rate of inputs, produce and the wages paid to the labourers. The data from the experiments were analysed statistically wherever treatment differences were found significance, the critical differences were worked out at $5 \%$ probability level $(\mathrm{P}=0.05)$. 


\section{Results and Discussion}

\section{Maize equivalent yield}

Complementary cropping and graded dose of fertilizers with organic amendments significantly influenced maize equivalent yield and given in Table 1. Higher maize equivalent yield was recorded by maize + cowpea +daincha $(6931 \mathrm{~kg} / \mathrm{ha})$ cropping followed by sunflower + greengram + daincha (4396kg/ha) cropping. Regarding fertilizer dose and organic amendments, application of $75 \%$ recommended NPK through fertilizers + $25 \% \mathrm{~N}$ through poultry manure recorded higher maize equivalent yield $(5865 \mathrm{~kg} / \mathrm{ha})$ and was followed application of $75 \%$ recommended NPK through fertilizers $+25 \%$ $\mathrm{N}$ through FYM. Interaction was significant. Higher miaze equivalent yield was recorded by maize + cowpea +daincha with $75 \%$ recommended NPK through fertilizers $+25 \%$ $\mathrm{N}$ through poultry manure $(7668 \mathrm{~kg} / \mathrm{ha})$ and was followed by maize + cowpea +daincha with $50 \%$ recommended NPK through fertilizers $+50 \% \mathrm{~N}$ through poultry manure $(7149 \mathrm{~kg} / \mathrm{ha})$. The later was comparable with maize + cowpea +daincha with $75 \%$ recommended NPK through fertilizers $+25 \%$ $\mathrm{N}$ through FYM $(6928 \mathrm{~kg} / \mathrm{ha})$. Because of enhanced growth characters with improved yield components, which led to higher grain yield. Moreover, higher concentration of macro and micronutrients in the poultry manure and higher and steady nutrient release compared to other organic amendments such FYM could make it to perform well (Ananda et al., 2006). The findings are in complete agreement with the findings of Sisodia and Kewat (2009). The supply of the required nutrients through organic and inorganic sources facilitated balanced nutrition of the crop, which might have resulted in enhanced grain yield. These findings are in agreement with those of Mukeshkumar et al (2012). Lowest maize equivalent yield was recorded by sunflower + greengram + daincha with application of $100 \%$ recommended NPK through fertilizers.

\section{Water productivity}

Water productivity was significantly influenced by complementary cropping and graded dose of fertilizers with organic amendments and given in Table 1 . Significantly higher water productivity was recorded by maize + cowpea + daincha ( 15.3 $\mathrm{kg} / \mathrm{ha} \mathrm{mm}$ ) cropping and lower water productivity was recorded by bhendi + onion + daincha $(7.9 \mathrm{~kg} / \mathrm{ha} \mathrm{mm})$ cropping. Regarding fertilizer dose and organic amendments, application of $75 \%$ recommended NPK through fertilizers $+25 \% \mathrm{~N}$ through poultry manure recorded higher water productivity $(12.3 \mathrm{~kg} / \mathrm{ha} \mathrm{mm})$ and was comparable to application of $75 \%$ recommended NPK through fertilizers $+25 \% \mathrm{~N}$ through FYM and $50 \%$ recommended NPK through fertilizers + $50 \% \mathrm{~N}$ through poultry manure.

\section{Post harvest soil fertility status}

\section{Soil available N}

Post harvest soil available $\mathrm{N}$ was not significantly influenced by complementary cropping systems but was significantly influenced by application of graded dose of fertilizers with organic amendments and given in Table 2. Higher post harvest soil available $\mathrm{N}(261.3 \mathrm{~kg} / \mathrm{ha})$ was recorded in application of $50 \%$ recommended NPK through fertilizers $+50 \% \mathrm{~N}$ through poultry manure which was statistically on par with application of $75 \%$ recommended NPK through fertilizers $+25 \%$ $\mathrm{N}$ through poultry manure $(259 \mathrm{~kg} / \mathrm{ha})$. Due to increase in microbial activity in the presence of organic matter, it released the available form of native and unavailable form of nutrients. Consequently, available nutrients status was enhanced (Singh et al., 2006) and when organic manure was added to the soil complex, nitrogenous compounds braked 
down slowly and made steady $\mathrm{N}$ supply throughout the growth period of the crop.

Higher post harvest soil available $\mathrm{N}$ was recorded in maize + cowpea +daincha with $50 \%$ recommended NPK through fertilizers + $50 \% \mathrm{~N}$ through poultry manure $(271 \mathrm{~kg} / \mathrm{ha})$. Lowest post harvest soil available $\mathrm{N}$ was recorded by sunflower + greengram + daincha with application of $100 \%$ recommended NPK through fertilizers.

\section{Soil available $\mathbf{P}$}

Complementary cropping systems does not significantly influence post harvest soil available $\mathrm{P}$ but post harvest soil available $\mathrm{P}$ was significantly influenced by application of graded dose of fertilizers with organic amendments (Table 2). Higher post harvest soil available $\mathrm{P}(18.9 \mathrm{~kg} / \mathrm{ha})$ was recorded in application of $50 \%$ recommended NPK through fertilizers $+50 \% \mathrm{~N}$ through poultry manure which was comparable with $50 \%$ recommended NPK through fertilizers $+50 \%$ $\mathrm{N}$ through FYM (17.6 kg/ha). Higher soil available $\mathrm{P}$ might be due to release of $\mathrm{CO}_{2}$ and organic acids during decomposition. This helps in solubilizing the native soil $\mathrm{P}$.

Table.1 Effect of complementary cropping and graded dose of fertilizers with organic amendments on maize equivalent yield, water productivity, post harvest $\mathrm{pH}$ and $\mathrm{EC}$

\begin{tabular}{|c|c|c|c|c|}
\hline Treatments & $\begin{array}{l}\text { Maize equivalent } \\
\text { yield (kg/ha) }\end{array}$ & $\begin{array}{c}\text { Water } \\
\text { productivity } \\
\text { (kg/ha mm) }\end{array}$ & pH & EC \\
\hline \multicolumn{5}{|l|}{ Main plot: Complementary cropping } \\
\hline$M_{1}:$ Maize + Cowpea + Daincha & 6931 & 15.3 & 8.56 & 0.53 \\
\hline $\mathrm{M}_{2}:$ Sunflower + Greengram + Daincha & 4396 & 9.7 & 8.58 & 0.54 \\
\hline$M_{3}:$ Bhendi + Onion + Daincha & 4369 & 7.9 & 8.56 & 0.53 \\
\hline 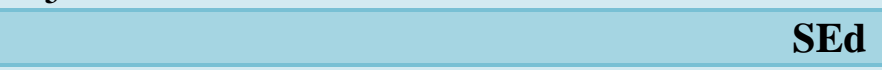 & 119 & 0.34 & 0.20 & 0.01 \\
\hline $\mathrm{CD}(\mathrm{p}=\mathbf{0 . 0 5})$ & 332 & 0.81 & NS & NS \\
\hline \multicolumn{5}{|c|}{ Subplot: Graded dose of fertilizers with organic amendments } \\
\hline $\begin{array}{l}S_{1}: \quad 100 \% \\
\text { fertilizers }\end{array}$ & 4553 & 9.5 & 8.96 & 0.60 \\
\hline $\begin{array}{l}S_{2}: 50 \% \text { recommended NPK through fertilizers } \\
+\mathbf{5 0 \%} \text { N through FYM }\end{array}$ & 4943 & 10.4 & 8.45 & 0.48 \\
\hline $\begin{array}{l}S_{3}: 75 \% \text { recommended NPK through fertilizers } \\
+25 \% \mathrm{~N} \text { through FYM }\end{array}$ & 5403 & 11.3 & 8.54 & 0.49 \\
\hline $\begin{array}{l}\mathrm{S}_{4}: 50 \% \text { recommended NPK through fertilizers } \\
+\mathbf{5 0 \%} \mathrm{N} \text { through poultry manure }\end{array}$ & 5395 & 11.3 & 8.39 & 0.54 \\
\hline $\begin{array}{l}S_{5}: 75 \% \text { recommended NPK through fertilizers } \\
+25 \% \mathrm{~N} \text { through poultry manure }\end{array}$ & 5865 & 12.3 & 8.49 & 0.56 \\
\hline SEd & 80 & 0.79 & 0.30 & 0.01 \\
\hline $\mathrm{CD}(\mathrm{p}=\mathbf{0 . 0 5})$ & 165 & 1.67 & NS & 0.03 \\
\hline
\end{tabular}


Table.2 Effect of complementary cropping and graded dose of fertilizers with organic amendments on post harvest soil fertility status

\begin{tabular}{|c|c|c|c|}
\hline \multirow[t]{2}{*}{ Treatments } & \multicolumn{3}{|c|}{ Post harvest soil fertility status (kg/ha) } \\
\hline & Available N & Available P & Available K \\
\hline \multicolumn{4}{|l|}{ Main plot: Complementary cropping } \\
\hline$M_{1}:$ Maize + Cowpea + Daincha & 244.4 & 17.9 & 181.0 \\
\hline$M_{2}:$ Sunflower + Greengram + Daincha & 244.2 & 16.6 & 173.0 \\
\hline$M_{3}:$ Bhendi + Onion + Daincha & 241.4 & 16.2 & 172.4 \\
\hline SEd & 2.7 & 0.67 & 2.0 \\
\hline $\mathrm{CD}(\mathrm{p}=\mathbf{0 . 0 5})$ & NS & NS & 5.4 \\
\hline \multicolumn{4}{|c|}{ Subplot: Graded dose of fertilizers with organic amendments } \\
\hline$S_{1}: 100 \%$ recommended NPK through fertilizers & 214.7 & 14.3 & 153.3 \\
\hline $\begin{array}{l}S_{2}: 50 \% \text { recommended NPK through fertilizers } \\
+50 \% \mathrm{~N} \text { through FYM }\end{array}$ & 249.0 & 17.6 & 172.0 \\
\hline $\begin{array}{l}\mathrm{S}_{3}: \mathbf{7 5 \%} \text { recommended NPK through fertilizers } \\
+25 \% \mathrm{~N} \text { through FYM }\end{array}$ & 232.7 & 16.6 & 162.0 \\
\hline $\begin{array}{l}\mathrm{S}_{4}: 50 \% \text { recommended NPK through fertilizers } \\
+\mathbf{5 0 \%} \mathrm{N} \text { through poultry manure }\end{array}$ & 261.3 & 18.9 & 199.7 \\
\hline $\begin{array}{l}S_{5}: 75 \% \text { recommended NPK through fertilizers } \\
+25 \% \mathrm{~N} \text { through poultry manure }\end{array}$ & 259.0 & 17.2 & 190.3 \\
\hline SEd & 5.3 & 0.68 & 4.5 \\
\hline $\mathrm{CD}(\mathrm{p}=\mathbf{0 . 0 5})$ & 11.0 & 1.41 & 9.4 \\
\hline
\end{tabular}

Table.3 Effect of complementary cropping and graded dose of fertilizers with organic amendments on economics

\begin{tabular}{|c|c|c|c|c|}
\hline Treatments & $\begin{array}{c}\text { Cost of } \\
\begin{array}{c}\text { cultivation } \\
\left.\text { ha }^{-1}\right)\end{array}\end{array}$ & $\begin{array}{c}\text { Gross } \\
\text { income }(\mathbf{R s} \\
\left.\text { ha }^{-1}\right)\end{array}$ & $\underset{\left.1_{1}\right)}{\text { Net income (Rs ha }}$ & $\begin{array}{c}\text { Benefit Cost } \\
\text { ratio }\end{array}$ \\
\hline M1S1 & 48661 & 123167 & 74506 & 2.53 \\
\hline M1S2 & 51248 & 135020 & 83772 & 2.63 \\
\hline M1S3 & 49954 & 138573 & 88619 & 2.77 \\
\hline M1S4 & 49671 & 142987 & 93316 & 2.88 \\
\hline M1S5 & 49166 & 153353 & 104187 & 3.12 \\
\hline M2S1 & 45370 & 73230 & 27860 & 1.61 \\
\hline M2S2 & 46368 & 78527 & 32159 & 1.69 \\
\hline M2S3 & 44559 & 93977 & 49418 & 2.11 \\
\hline M2S4 & 45667 & 92330 & 46663 & 2.02 \\
\hline M2S5 & 44209 & 101530 & 57321 & 2.30 \\
\hline M3S1 & 45486 & 76793 & 31307 & 1.69 \\
\hline M3S2 & 45531 & 83047 & 37516 & 1.82 \\
\hline M3S3 & 44016 & 91610 & 47594 & 2.08 \\
\hline M3S4 & 46137 & 88425 & 42288 & 1.92 \\
\hline M3S5 & 44318 & 97035 & 52717 & 2.19 \\
\hline
\end{tabular}


The organic matter may also reduce the fixation of phosphate by providing protective cover on sesqueoxides and chelating catons like $\mathrm{Ca}^{2+}$ and $\mathrm{Mg}^{2+}$ (when applied along with inorganic fertilizer) which in turn enhanced the availability of P (Singh et al., 2010) and build up of available phosphorus in soil was released from organic acids during the microbial decomposition of organic manures which help to improve native phosphorous content of soil. Higher post harvest soil available $\mathrm{P}$ was recorded in maize + cowpea +daincha with $50 \%$ recommended NPK through fertilizers $+50 \% \mathrm{~N}$ through poultry manure $(19.2 \mathrm{~kg} / \mathrm{ha})$, Lowest post harvest soil available $\mathrm{P}$ was recorded by sunflower + greengram + daincha with application of $100 \%$ recommended NPK through fertilizers.

\section{Soil available K}

Complementary cropping systems and application of graded dose of fertilizers with organic amendments significantly influenced post harvest soil available K (Table 2). Higher post harvest soil available $\mathrm{K}$ was recorded by maize + cowpea +daincha (181 kg/ha) cropping which was followed by sunflower+ greengram+ daincha $(173 \mathrm{~kg} / \mathrm{ha})$ cropping. Regarding graded dose of fertilizers with organic amendments, higher post harvest soil available K (199.7 kg/ha) was recorded in application of $50 \%$ recommended NPK through fertilizers $+50 \% \mathrm{~N}$ through poultry manure which was statistically on par with application of $75 \%$ recommended NPK through fertilizers $+25 \% \mathrm{~N}$ through poultry manure $(190.3 \mathrm{~kg} / \mathrm{ha})$. The available nutrients in soil increased due to treatments incorporating either total or part of nutrients through organic sources as compared to inorganic sources. This may be due to the release of aliphatic and aromatic hydroxy acids, humates and lignins from organic manures which would release the nutrients into the soil (Aruna et al., 2012).

\section{Post harvest soil pH and EC}

Complementary cropping systems does not significantly influenced post harvest soil $\mathrm{pH}$ and EC. Post harvest soil EC was significantly influenced by application of graded dose of fertilizers with organic amendments and given in Table 1. Higher post harvest soil EC was recorded with application of $100 \%$ recommended NPK through fertilizers. This was followed $75 \%$ recommended NPK through fertilizers $+25 \%$ $\mathrm{N}$ through poultry manure. Lower EC was recorded by $50 \%$ recommended NPK through fertilizers $+50 \% \mathrm{~N}$ through FYM.

\section{Economics}

The economic analysis (Table 3) indicated that higher gross return, net return and $\mathrm{B}$ : C ratio was realized with maize + cowpea +daincha with $75 \%$ recommended NPK through fertilizers $+25 \% \mathrm{~N}$ through poultry manure and was followed by maize + cowpea +daincha with $50 \%$ recommended NPK through fertilizers $+50 \% \mathrm{~N}$ through poultry manure. Higher crop productivity with lesser cost of cultivation could result in better economic parameters like higher net returns and $\mathrm{B}: \mathrm{C}$ ratio. Similar view was expressed by Meena et al (2010). Lowest gross income, net income and $\mathrm{B}$ : $\mathrm{C}$ ratio was recorded by sunflower + greengram + daincha with application of $100 \%$ recommended NPK through fertilizers. The highest cost of cultivation was realized in maize + cowpea + daincha with $50 \%$ recommended NPK through fertilizers $+50 \% \mathrm{~N}$ through FYM plots.

In sodic soil, higher maize equivalent yield, water productivity, net income and $\mathrm{B}: \mathrm{C}$ ratio was recorded by maize + cowpea + daincha with application of $75 \%$ recommended NPK through fertilizers $+25 \% \mathrm{~N}$ through poultry manure and was comparable with maize + 
cowpea + daincha with $25 \% \mathrm{~N}$ supplied through FYM for yield and water productivity. FYM application resulted in increased cost of cultivation due to the low nutrient content compared to poultry manure. A complementary cropping of maize + cowpea + daincha with application of $75 \%$ recommended NPK through fertilizers $+25 \%$ $\mathrm{N}$ through poultry manure may be recommended for sodic soils.

\section{References}

Ananda, M.G., M.R.Ananda, V.C. Reddy and Ajayakumar, M.Y. 2006. Influence of different organic sources on yield and its components and benefit cost ratio of paddy (Oryza sativa L.) and groundnut (Arachis hypogaea L.) in paddy groundnut cropping system. Crop Research 31(3): 329-333.

Aruna, P., G. Prabhakara Reddy and Karuna Sagar,G. 2012. Effect of integrated nitrogen management on growth, yield, quality and post - harvest nutrient status of soil in aerobic rice (Oryza sativa L.). Crop Research 43 (1, 2 \& 3): 1-4.

Clark, G. J., N. Dodgshun, P.G. Sale and Tang, C. 2007. Changes in chemical and biological properties of a sodic clay subsoil with addition of organic amendments. Soil Biol. \& Biochem.,39: 2806-2817.
Meena, R.N., S.P. Singh and Kalyan Singh. 2010. Effect of organic nitrogen nutrition on yield, quality, nutrient uptake and economics of rice (Oryza sativa) - table pea (Pisum sativum var. hortense) - onion (Allium cepa) cropping sequence. Indian J. Agri Sci. 80 (1):1003-1006.

Mukeshkumar, N.P.S. Yaduvanshi and Singh. Y.V. 2012. Effects of integrated nutrient management on rice yield, nutrient uptake and soil fertility status in reclaimed sodic soils. J. Indian Soc. Soil Sci. 60 (2): 132-137.

Singh, R.P., A.S.Rathi, D.Srinivas, T.V.Sridhar, A. Srinivas and Upendra Rao, A.2010. Effect of organic and inorganic nutrition on soil and productivity of rice under rice- rice system. Oryza 47 (2): 123-127.

Singh, R.P., P.K. Yadav, R.K. Singh, S.N. Singh, M.K. Bisen and Singh, J. 2006. Effect of chemical fertilizer, FYM and biofertilizer on performance of rice and soil properties. Crop Research 32 (3): 283-285.

Sisodia, V. and Kewat, M.L. 2009. Effect of different organic sources on quality and yield of hybrid rice (Oryza sativa). Inter J. of Agri. Environ. \& Biotech. 2 (1): 35-37.

\section{How to cite this article:}

Shanmugam, P. M. and Somasundaram, S. 2020. Maximization of Productivity in Sodic Soil through Bio-Intensive Complementary Cropping System with Organic Amendments. Int.J.Curr.Microbiol.App.Sci. 9(07): 2527-2533. doi: https://doi.org/10.20546/ijcmas.2020.907.296 